\title{
Evidence for the Presence of Insulin Binding Sites in Isolated Rat Intestinal Epithelial Cells*
}

\author{
M. E. Forgue-Lafitte, M. R. Marescot, M. C. Chamblier, and G. Rosselin \\ Unité de Recherche de Diabétologie et d'Etudes Radio-Immunologiques des Hormones Protéiques, U.55 (INSERM), \\ Hôpital Saint-Antoine, Paris, France
}

Summary. Insulin receptors have been demonstrated in isolated rat intestinal epithelial cells. The specific binding of ${ }^{125} \mathrm{I}$-insulin was time - and temperature dependent, the optimal temperature of study being $15^{\circ}$. Dissociation of bound ${ }^{125} \mathrm{I}$-insulin by an excess of unlabelled hormone was rapid and attained $66 \pm 2 \%$ in $2 \mathrm{~h}$. When initiated by dilution, the dissociation attained $35 \pm 4 \%$ in $2 \mathrm{~h}$, and $72 \pm 1 \%$ in $2 \mathrm{~h}$ when $10^{-7} \mathrm{~mol} / 1$ unlabelled insulin was added. The $\mathrm{pH}$ optimum for the binding process was between 7.5 and 8 , and the binding increased proportionally to cell protein concentration up to $1.5 \mathrm{mg} / \mathrm{ml}$. Under standard conditions $\left(2 \mathrm{~h}\right.$ at $\left.15^{\circ}\right)$ the degradation of the labelled hormone in the medium accounted for $20-50 \%$ of total tracer, depending on the concentration of cells. At apparent equilibrium $\left(2 \mathrm{~h}\right.$ at $\left.15^{\circ}\right)$, unlabelled insulin in the range of $10^{-10}$ to $10^{-7} \mathrm{~mol} / 1$ inhibited competitively the binding of 4.3-7 $\times$ $10^{-11} \mathrm{~mol} / \mathrm{L}^{125} \mathrm{I}$-insulin; fifty per cent inhibition was obtained with $3 \times 10^{-9} \mathrm{~mol} / \mathrm{l}$ native insulin. Scatchard analysis, after correction for degradation, gave curvilinear plots, that may be explained by two orders of binding sites, with $2,000 \pm 200$ sites/cell of high affinity $\left(\mathrm{Ka}=2.2 \pm 0.2 \times 10^{9} \mathrm{l} / \mathrm{mol}\right)$ and $39,000 \pm$ 3,000 sites $/$ cell of low affinity $(\mathrm{Ka}=5.6 \pm 1.6 \times$ $10^{7} \mathrm{l} / \mathrm{mol}$ ). The potency of proinsulin to compete with ${ }^{125}$ I-insulin for the binding site was $3 \%$ that of insulin, unrelated peptides were inactive. Such results give a molecular basis to different reports suggesting that the intestine could be a target-tissue for insulin.

Key words: Insulin receptors, insulin degradation, enterocytes, epithelial cells, intestine.

\footnotetext{
* Presented at the 10th Meeting of the International Diabetes Federation, Vienna, 1979
}

Several lines of evidence indicate that intestinal epithelial cells, as other cells in the organism, exhibit specific binding sites for peptide hormones that might intervene in their regulation. Thus, binding sites for VIP [37] that are related to a cyclic AMP system [23] have been characterised. However, no studies were performed so far on the binding of insulin in the intestinal epithelium. The aims of this paper were to investigate insulin binding sites in rat isolated intestinal epithelial cells and if present, to define the characteristics of these binding sites as compared to those found in known target-tissues for the hormone $[1,10,12,14,27,33,35,43]$.

\section{Material and Methods}

\section{Chemicals}

Pork monocomponent insulin was iodinated by the chloramine $\mathrm{T}$ method to a specific activity of $150-180 \mu \mathrm{Ci} / \mu \mathrm{g}(0.4-0.5$ atom of iodine per molecule, purified on Sephadex G 50 [30], and tested prior to use for its ability to bind to rat liver plasma membranes [12]. Pork monocomponent insulin, crystalline beef insulin, pork proinsulin were obtained from Novo, Novoallé, DK-2880 Bagsvaerdt (Denmark). Human growth hormone was obtained from Prof. Dray, Institut Pasteur, Paris. Bovine serum albumin (BSA) fraction V, was obtained from Miles Laboratories, Elkhardt, IN 46514, USA. Fatty acid free BSA was obtained from Sigma, P. O. Box 14508, St. Louis, M. O. 63178, USA. Epidermal growth factor was a generous gift of Dr. Moody, Novo Research Institute, 215 Nordre Fasanvej, DK-2200 Copenhagen (Denmark). All chemicals were of reagent grade.

\section{Methods \\ Preparation of Cells. Intestinal epithelial cells were isolated from female Sprague-Dawley rats (160-200 g), fed ad libitum, accord- ing to a modification [22,37] of the method of Mitjavila et al. [32]. Briefly, the jejuno-ileum was excised, flushed with an ice-cold

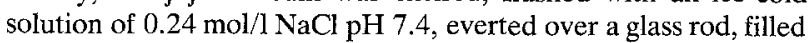


with $0.34 \mathrm{~mol} / 1 \mathrm{NaCl} \mathrm{pH} \mathrm{7.4,} \mathrm{and} \mathrm{washed} \mathrm{with} \mathrm{a} \mathrm{dispersing} \mathrm{solu-}$ tion containing $2.5 \mathrm{mmol} / 1 \mathrm{EDTA}$ and $0.24 \mathrm{~mol} / 1 \mathrm{NaCl} \mathrm{pH} 7.4$. The cells were obtained by mild hand-shaking, sedimented at $200 \mathrm{~g}$ for $2 \mathrm{~min}$, and washed 5 times in $100 \mathrm{ml}$ of $0.15 \mathrm{~mol} / \mathrm{l} \mathrm{NaCl}$. The preparations contained almost exclusively villous cells as attested by the presence of brush borders (microvilli) in $90-95 \%$ of the cells, and were free of non epithelial cells and parasites. Cells that excluded trypan blue were more than $90 \%$ after $4 \mathrm{~h}$ at $15^{\circ}$, and $95 \%$ after $1 \mathrm{~h} 30$ at $30^{\circ}$. The cell preparation oxidised glucose and synthesized proteins in a linear fashion during $2 \mathrm{~h}$ at $15^{\circ}$ (Laburthe, personal communication). Protein concentration was measured by the method of Lowry et al. [28];106 cells contained $0.24 \mathrm{mg}$ of protein [37].

Binding Studies. Isolated cells $(0.11-3.75 \mathrm{mg} / \mathrm{ml}$ of cell protein) were incubated in duplicate or triplicate samples with fixed concentrations of ${ }^{125} \mathrm{I}$-insulin $\left(5 \times 10^{-11}\right.$ to $\left.7.8 \times 10^{-11} \mathrm{~mol} / \mathrm{l}\right)$ in $0.5 \mathrm{ml}$ of Krebs Ringer phosphate buffer (KRP) containing $1 \mathrm{~g}$ per $100 \mathrm{ml}$ of BSA, pH 7.8 unless stated otherwise. Fatty acid-free BSA has been used in all experiments (except for Fig. 4). Kinetics studies were performed at 15 and $30^{\circ}$. Equilibrium studics were performed during $2 \mathrm{~h}$ at $15^{\circ}$, in the presence of 0 to $10^{-7} \mathrm{~mol} / 1$ unlabelled porcine insulin. After incubation, cell-bound insulin was separated by rapid centrifugation as described elsewhere [12] and the radioactivity of the washed pellets determined by gamma spectrometry. Data are reported as specific binding: this is obtained by subtracting from the total the non-specific binding, $i$. e. the amount of labelled insulin that is not displaced by an excess $\left(1.6 \times 10^{-5} \mathrm{~mol} / \mathrm{l}\right)$ of unlabelled insulin. For dissociation by an excess of unlabelled hormone, the incubation was conduced at $15^{\circ}$ for $2 \mathrm{~h}$ (time 0 of dissociation), in conditions previously described; then $10^{-7} \mathrm{~mol} / 1$ unlabelled insulin was added in a small volume and the cell-bound radioactivity separated after various times of incubation as described above. Non-specific binding was subtracted at each point. For dissociation by dilution, the incubation

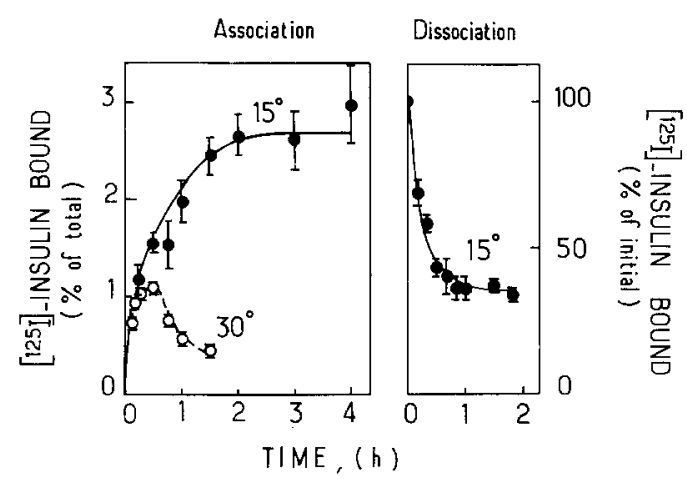

Fig. 1. Left: Time curves of ${ }^{125} \mathrm{I}$-insulin binding to enterocytes at $30^{\circ}$ (open circles) and $15^{\circ}$ (closed circles). Cells $(0.82-1.44 \mathrm{mg} / \mathrm{ml}$ of cell protein) were incubated with $5 \times 10^{-11} \mathrm{~mol} / 1^{125} \mathrm{I}$-insulin for the times indicated on the abscissa. Specific binding was determined as described in Methods, each point is the mean \pm SEM of 3 separate experiments, each performed in duplicate. The values are normalised to $1 \mathrm{mg} / \mathrm{ml}$ of cell protein. Right: Dissociation of bound ${ }^{125} \mathrm{I}$-insulin to enterocytes at $15^{\circ}$ by an excess of unlabelled insulin. Cells $(0.67 \mathrm{mg} / \mathrm{ml}$ of cell protein) were incubated for $2 \mathrm{~h}$ at $15^{\circ}$ with $7.5 \times 10^{-11} \mathrm{~mol} / 1^{125} \mathrm{I}$-insulin and the specific binding determined. This corresponds to $100 \%$ on the ordinate, time 0 of dissociation. Then $10^{-7} \mathrm{~mol} / 1$ unlabelled insulin was added in a small volume, and the incubation continued for various lengths of time as indicated on the abscissa, and the specific binding determined. Each point is the mean \pm SEM of triplicate determinations in a single experiment was conducted at $15^{\circ}$ for $2 \mathrm{~h}$ (time 0 of dissociation); then $10 \mathrm{ml}$ of KRP containing $0.1 \mathrm{~g} / 100 \mathrm{ml}$ of BSA and, when indicated, $10^{-7} \mathrm{~mol} / 1$ unlabelled insulin were added and the cell-bound radioactivity separated by filtration on glass fibre filters (Whatman, GFC, Whatman-Ltd, Maidstone, England) after various times of incubation. The filters were then rinsed three times with $5 \mathrm{ml}$ of ice-cold buffer (KRP containing $0.1 \mathrm{~g} / 100 \mathrm{ml}$ of BSA) and counted in a gamma spectrometer. Non-specific binding was subtracted at each point.

Degradation of ${ }^{125} I$-insulin. The integrity of insulin in the incubation medium was tested by its ability to bind to liver plasma membranes as previously described [13]. The degradation is expressed as $\%$ of unaltered insulin present in control simultaneously incubated without cells.

Degradation of Binding Sites. The degradation of binding sites was tested by preincubation of the cells at the temperature considered, followed by an incubation with ${ }^{125} \mathrm{I}$-insulin for $2 \mathrm{~h}$ at $15^{\circ}$. The binding to these cells was compared to the binding to control cells (not preincubated)

Scatchard Analysis. The results obtained from competition experiments were analysed by the method of Scatchard [39]. In order to avoid interference between degradation of insulin and quantitative data, we corrected Scatchard analysis for degradation according to the method of Kahn et al. [20]. The following equation was applied to each point:

$$
\frac{\mathrm{B}}{\mathrm{F}}(\text { corrected })=\frac{\mathrm{B}-\mathrm{NS}}{\mathrm{FX}(1-\mathrm{DF})}
$$

where $\mathrm{B}=$ bound hormone,

$\mathrm{F}=$ free hormone,

NS = non specific binding,

$\mathrm{DF}=$ fraction of hormone degraded

For the calculations concerning the high affinity sites (Fig. 5, right, slope $\mathrm{C}$ ) the contribution of the low affinity sites has been subtracted from each point: $\mathrm{C}=\mathrm{A}-\mathrm{B}$.

Statistical Methods. Numerical results are expressed as means \pm SEM of several experiments, or as means of duplicate determinations or means \pm SEM of triplicate determinations in a single experiment. For Scatchard analysis [39], in each individual experiment, the regression lines were obtained from the experimental points using the method of least squares.

\section{Results}

\section{Kinetics of Binding}

Association. The binding of ${ }^{125} \mathrm{I}$-insulin to rat enterocytes was time - and temperature - dependent. (Fig. 1, left panel). At $30^{\circ}$, binding was unstable, reached a peak ( $1.08 \pm 0.04 \%$ of total radioactivity) in $30 \mathrm{~min}$ and then decreased rapidly. At $15^{\circ}$, binding increased with time, reached a plateau $(2.6 \pm 0.3 \%$ of total) in $2 \mathrm{~h}$, and then remained constant until at least $4 \mathrm{~h}$. Non specific binding varied with time and temperature, attaining $49 \pm 4 \%$ of total binding in $30 \mathrm{~min}$ at $30^{\circ}$ and $25 \pm 3 \%$ in $2 \mathrm{~h}$ at $15^{\circ}$. The absence of steady state of binding at $30^{\circ}$ was presumably due 
to the degradation of ${ }^{125} \mathrm{I}$-insulin (Table 1), the rise of non specific binding ( $49 \pm 4 \%$ of total binding after $30 \mathrm{~min}$, and $74 \pm 5 \%$ after $90 \mathrm{~min}$ ) and the degradation of binding sites (see forward). No amelioration could be obtained by the use of insulin degradation inhibitors $[13,25]$ like bacitracin $(1.5 \mathrm{mg} / \mathrm{ml})$, $\mathrm{N}$-Ethyl maleimide $(1-10 \mathrm{mmol} / \mathrm{l})$, aprotinin $(1500$ $\mathrm{U} / \mathrm{ml}$ ) or iodoacetamide $(54 \mathrm{mmol} / \mathrm{l})$. At the concentrations cited above, previously shown to protect insulin from degradation $[13,25]$, these substances were toxic to the cells and lowered total binding. Lowering temperature (Table 1) and adding unlabelled hormone (see forward) resulted in a clear decrease in the degradation of insulin. For all these reasons, all subsequent studies were performed at $15^{\circ}$, without inhibitor.

Table 1. Time course of degradation of ${ }^{125}$ I-insulin at 15 and $30^{\circ}$

\begin{tabular}{lllll}
\hline $15^{\circ}$ & & & $30^{\circ}$ \\
\cline { 1 - 1 } $\begin{array}{l}\text { Time } \\
\text { (h) }\end{array}$ & $\begin{array}{l}\text { \% of } \\
\text { degradation }\end{array}$ & & $\begin{array}{l}\text { Time } \\
\text { (min) }\end{array}$ & $\begin{array}{l}\% \text { of } \\
\text { degradation }\end{array}$ \\
\hline 0.5 & $18 \pm 1$ & 15 & $22 \pm 1$ \\
1 & $30 \pm 8$ & 30 & $40 \pm 7$ \\
2 & $42 \pm 7$ & 60 & $64 \pm 11$ \\
4 & $55 \pm 9$ & 90 & $71 \pm 10$ \\
\hline
\end{tabular}

The supernatants of experiments shown in Figure 1 were tested for insulin integrity as described in Methods. Each value is the mean \pm SEM of three separate experiments

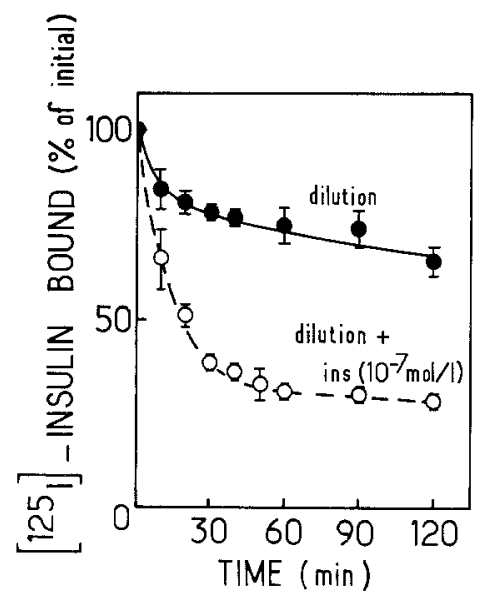

Fig. 2. Dissociation of bound ${ }^{125} \mathrm{I}$-insulin to enterocytes at $15^{\circ}$, initiated by dilution (closed circles) and dilution plus $10^{-7} \mathrm{~mol} / 1$ unlabelled insulin (open circles). Enterocytes (protein concentration $0.82 \mathrm{mg} / \mathrm{ml}$ ) were incubated with $7.8 \times 10^{-11} \mathrm{~mol} / 1^{125}$ I-insulin for $2 \mathrm{~h}$ at $15^{\circ}$. This corresponds to $100 \%$ on the ordinate, time 0 of dissociation. After dilution of the incubation medium $(\times 20)$, the specific binding was determined by filtration (as indicated under Methods) at the times indicated on the abscissa. Each value is the mean \pm SEM of triplicate determinations in a single experiment
Dissociation. Dissociation, at $15^{\circ}$, of bound ${ }^{125} \mathrm{I}$-insulin by $10^{-7} \mathrm{~mol} / 1$ unlabelled insulin is shown in Figure 1, right panel. Dissociation was rapid, with $50 \%$ of bound ${ }^{125} \mathrm{I}$-insulin dissociated in $20-30 \mathrm{~min}$; after $2 \mathrm{~h}, 34 \pm 2 \%$ of labelled hormone remained associated with the cells. Figure 2 shows the dissociation, at $15^{\circ}$, of ${ }^{125} \mathrm{I}$-insulin bound to enterocytes by dilution $(\times 20)$ of the incubation medium. By dilution alone, the dissociation was weak, attaining $22 \pm$ $1 \%$ and $35 \pm 4 \%$ of initial binding in 30 and $120 \mathrm{~min}$, respectively. The maximal dissociation was obtained by addition of $10^{-7} \mathrm{~mol} / 1$ unlabelled insulin to the medium of dilution. In these conditions, $72 \pm$ $1 \%$ of labelled hormone was dissociated after $120 \mathrm{~min}$. The addition of a higher concentration of unlabelled insulin $\left(1.6 \times 10^{-5} \mathrm{~mol} / 1\right)$ resulted in a

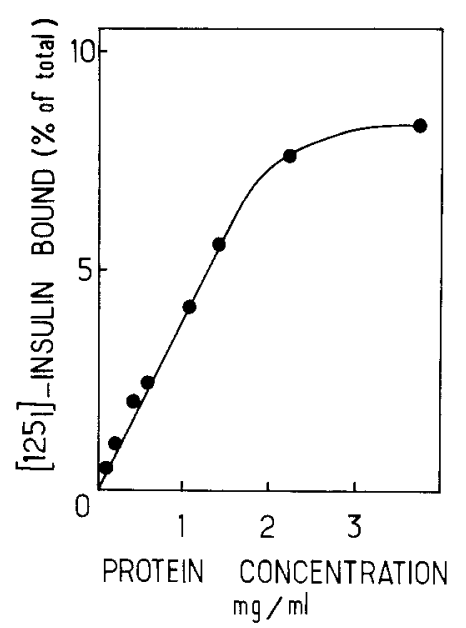

Fig. 3. Binding of ${ }^{125} \mathrm{I}$-insulin as a function of the concentration of cell protein. Enterocytes ( 0.11 to $3.75 \mathrm{mg} / \mathrm{ml}$ of cell protein) were incubated at the different concentrations indicated on the abscissa with $7.2 \times 10^{-11} \mathrm{~mol} / \mathrm{L}^{125} \mathrm{I}$-insulin for $2 \mathrm{~h}$ at $15^{\circ}$. Each value is the mean of duplicate determinations in a single experiment

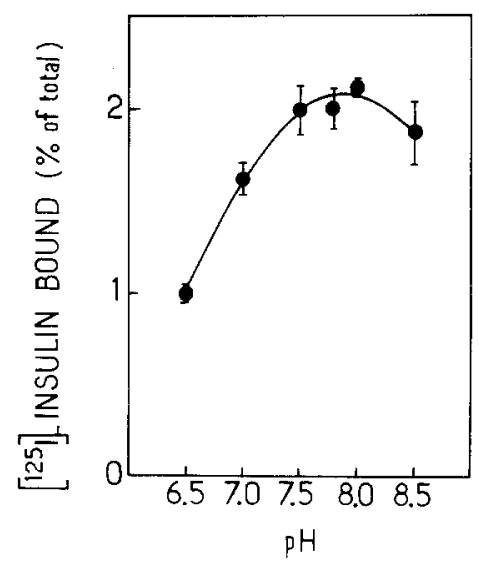

Fig. 4. $\mathrm{pH}$ dependence of insulin binding. Enterocytes $(0.54 \mathrm{mg} / \mathrm{ml}$ of cell protein) were incubated with ${ }^{125} \mathrm{I}$-insulin $\left(6 \times 10^{-11} \mathrm{~mol} / \mathrm{l}\right)$ at the $\mathrm{pH}$ values indicated for $2 \mathrm{~h}$ at $15^{\circ}$. Each value is the mean \pm SEM of triplicate determinations in a single experiment 
lower dissociation than that obtained with $10^{-7} \mathrm{~mol} / \mathrm{l}$ (data not shown), in agreement with the previous observations by De Meyts et al. [9].

\section{Effect of Cell Protein Concentration and $\mathrm{pH}$}

Results (Fig. 3) indicated a linear relationship between ${ }^{125} \mathrm{I}$-insulin binding and the amount of cell protein concentration in the range of 0.1 to $1.5 \mathrm{mg} / \mathrm{ml}$. For higher concentrations, the binding increased more slowly.

Figure 4 shows the $\mathrm{pH}$ dependence of ${ }^{125} \mathrm{I}$-insulin binding to rat enterocytes at $15^{\circ}$. The $\mathrm{pH}$ value optimum was between 7.5 and 8 . All other experiments were performed at $\mathrm{pH} 7.8$ and with concentrations of cell protein below $1.5 \mathrm{mg} / \mathrm{ml}$.

\section{Degradation of Insulin and Binding Sites}

The degradation of ${ }^{125} \mathrm{I}$-insulin in the medium increased with temperature (Table 1) and with the concentration of cell protein (Table 2). The amount of tracer degraded in the medium after $1 \mathrm{~h}$ accounted for $30 \pm 8$ and $64 \pm 11 \%$ at 15 and $30^{\circ}$, respectively (Table 1). Under the conditions of incubation used $\left(0.5\right.$ to $1.5 \mathrm{mg} / \mathrm{ml}$ of cell protein, $2 \mathrm{~h}$ at $\left.15^{\circ}\right)$, the degradation was also dependent on the concentration of insulin (labelled plus unlabelled) added to the medium: for example, with $1.2 \mathrm{mg} / \mathrm{ml}$ of cell protein, the degradation of insulin was $43,29,21$ and $18 \%$ in the presence of $4 \times 10^{-11}, 1.4 \times 10^{-10}, 5.4 \times 10^{-10}$ and $10^{-9} \mathrm{~mol} / 1$ insulin, respectively.

No degradation of the binding sites could be detected after $2 \mathrm{~h}$ at $15^{\circ}$. At $30^{\circ}, 25 \%$ of the binding sites were degraded after $1 \mathrm{~h}$ (data not shown).

\section{Concentration Dependence of Insulin Binding}

The concentration dependence of insulin binding was determined by adding increasing concentrations of unlabelled insulin $\left(10^{-10}\right.$ to $\left.10^{-7} \mathrm{~mol} / \mathrm{l}\right)$ to a fixed concentration of ${ }^{125} \mathrm{I}$-insulin in the incubation mixture

Table 2. Degradation of ${ }^{125} \mathrm{I}$-insulin $\left(7 \times 10^{-11} \mathrm{~mol} / \mathrm{l}\right)$ as a function of cell protein

\begin{tabular}{lllllll}
\hline $\begin{array}{l}\text { Concentration of } \\
\text { cell protein } \\
\% \text { of }{ }^{125} \text { I-insulin } \\
\text { degraded } \\
\text { after } 2 \text { h at } 15^{\circ}\end{array}$ & 0.44 & 0.60 & 1.10 & 2.24 & 3.75 \\
\hline
\end{tabular}

The supernatants from experiment shown in Figure 3 were assayed for insulin integrity as described in Methods. Each value is the mean of duplicate determinations under the conditions of apparent equilibrium. Native insulin reduced tracer binding in a dose-dependent fashion, half-maximum binding being obtained at about $3 \times 10^{-9} \mathrm{~mol} / 1$ unlabelled insulin (Fig. 5, left). Scatchard analysis of the binding data (Fig. 5, right), gave curvilinear plots similar to those obtained for insulin in various tissues [21]. That may be explained by two independent binding sites and/or negative cooperativity [9]. In order to compare the data with those of others on a quantitative basis, we performed the calculations following the Scatchard method [39]. As calculated from the curves obtained from individual experiments, the numbers of binding sites per cell were $2,000 \pm 200$ and $39,00 \pm 3,000$ of high and low affinity, the corresponding constants being $2.2 \pm$ $0.2 \times 10^{9} 1 / \mathrm{mol}$ and $5.6 \pm 1.6 \times 10^{7} \mathrm{l} / \mathrm{mol}$, respectively (mean \pm SEM of 6 separate experiments).

\section{Specificity of Binding}

The specificity of binding was tested in competition experiments between ${ }^{125} \mathrm{I}$-insulin $\left(5 \times 10^{-11} \mathrm{~mol} / \mathrm{l}\right)$, unlabelled insulin $\left(5 \times 10^{-10}\right.$ to $\left.10^{-7} \mathrm{~mol} / \mathrm{l}\right)$, proinsulin $\left(10^{-9}\right.$ to $\left.10^{-6} \mathrm{~mol} / \mathrm{l}\right)$ and unrelated peptides. Fifty per cent of the labelled hormone was displaced by $10^{-7} \mathrm{~mol} / 1$ proinsulin, indicating that the ability of proinsulin to bind to enterocytes was $3 \%$ that of native insulin. Human growth hormone $\left(10^{-6} \mathrm{~mol} / \mathrm{l}\right)$, glucagon $\left(10^{-6} \mathrm{~mol} / \mathrm{l}\right)$ and epidermal growth factor $\left(10^{-6} \mathrm{~mol} / \mathrm{l}\right)$ did not compete with ${ }^{125} \mathrm{I}$-insulin for the binding site (data not shown).
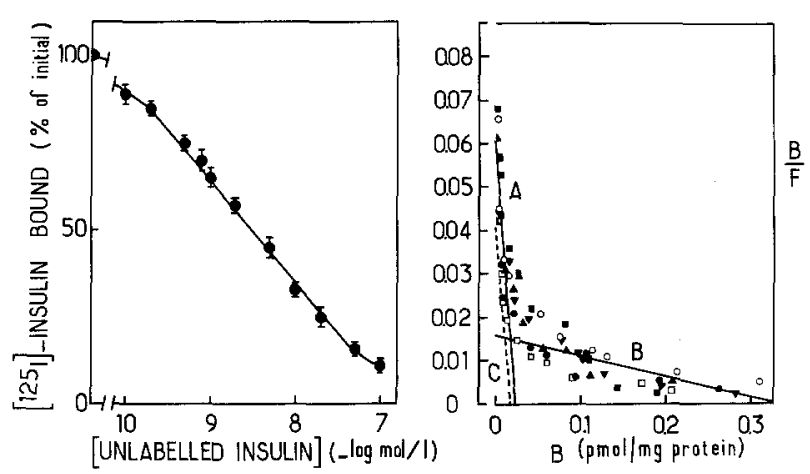

Fig. 5. Left: concentration dependence of insulin binding. Enterocytes $(0.99-1.44 \mathrm{mg} / \mathrm{ml}$ of cell protein) were incubated for $2 \mathrm{~h}$ at $15^{\circ}$ with ${ }^{125} \mathrm{I}$-insulin $\left(4.9-7 \times 10^{-11} \mathrm{~mol} / \mathrm{l}\right)$ in the absence $(100 \%$ on the ordinate) and presence of increasing concentrations of unlabelled insulin $\left(10^{-10}\right.$ to $\left.10^{-7} \mathrm{~mol} / \mathrm{l}\right)$. Each value is the mean \pm SEM of 6 separate experiments, each performed in duplicate. Right: individual Scatchard plots obtained from the data (see Methods). The same symbols indicate measurements performed in a single experiment. The continuous lines $\mathrm{A}$ and $\mathrm{B}$ represent the mean of the individual lines derived from the experimental points of each individual Scatchard plot. In dotted lines is $\mathrm{C}=\mathrm{A}-\mathrm{B}$ (see Methods) 


\section{Discussion}

\section{Binding Assay of Insulin}

The main characteristics of the insulin binding sites on rat enterocytes are similar to those described in other systems: The high affinity constant of the insulin-receptor interaction is of the same order of magnitude than that obtained for rat liver membranes [12]. The numbers of sites/cell are comparable with those given for isolated human adipocytes [1] and cancer colon cells [11]. The temperature and $\mathrm{pH}$ dependence of binding is also in accordance with the results obtained in other systems for the binding of insulin to its receptors $[14,16,32,35,43,44]$. The specificity of binding of ${ }^{125} \mathrm{I}$-insulin to enterocytes, as tested with proinsulin and unrelated peptides is the same that in liver membranes [12]. The studies of dissociation of ${ }^{125} \mathrm{I}$-insulin from rat enterocytes (Fig. 2) indicate that the insulin receptors of rat enterocytes exhibit a property which may be negative cooperativity [9] or other causes of non linear Scatchard plots $[36,41]$. This property is described for many insulin receptors $[2,9,21,35,36,44]$, and seems to be a common feature for all systems used to measure insulin binding [21].

\section{Degradation of Insulin}

The degradation of ${ }^{125} \mathrm{I}$-insulin was reduced by performing the experiments at $15^{\circ}$ as was described for the binding of insulin to other isolated cells $[2,16$, $34,35,44,45]$. Degradation increased with the concentration of cells (Table 2), but was reduced in the presence of small quantities of unlabelled hormone. Terris and Steiner [42] have postulated that the degradation of insulin by isolated hepatocytes requires its prior association with receptors. However, in the case of enterocytes, it would be difficult to distinguish between a "specific" degradation of the hormone, and a "non-specific" degradation due to the enzymes present in the brush border membrane, which is not in contact with insulin under physiological conditions. In favour of the latter hypothesis, no degradation of insulin was detected at $37^{\circ}$ by attached cancer colon cells HT 29 [11], and only weak degradation $\left(10 \%\right.$ after $2 \mathrm{~h}$ at $\left.15^{\circ}\right)$ by detached cancer duodenum cells HUTU 80 (Cezard et al., in preparation). Similarly, the fact that the dissociation of bound ${ }^{125}$ I-insulin is incomplete can be explained, at least for a part, by an internalisation of intact or degraded hormone $[6,17]$. As it was shown for human monocytes [3] and rat hepatocytes [42] the labelled compounds released from the cells may be degraded ${ }^{125}$ I-insulin.

\section{Insulin Action}

The presence of insulin receptors in rat enterocytes gives a molecular basis to observations reported about the physiological role of insulin in the intestine. Until recently, the biological activity of insulin on the digestive tube has been doubtful and conflicting $[4,7$, $8,15,19,26]$. These discrepancies may be due to the fact that most studies were performed in vivo and that insulin does not seem to stimulate, in the intestine, the uptake of glucose and amino-acids $[4,7,8$, $15,19,26]$, which is one of the specific actions of insulin on target-tissues $[19,24$,$] . However, when$ injected in vivo to diabetic rats, insulin restores to normal the depressed $\mathrm{Ca}^{2+}$ transport [40]. In addition, insulin injected to control rats stimulates the brush border enzymes activities such as lactase and sucrase [29]. When added in vitro, insulin increases the cGMP content of scraped rabbit ileal mucosa [5] and stimulates slightly the guanylate cyclase activity of isolated brush border and basolateral membranes of the rat duodenum [46]. The hormone also intervenes in the ontogenesis of mouse intestinal sucrase and so seems to play a role in intestinal maturation [31]. Furthermore, insulin stimulates growth and macromolecules synthesis in two human intestinal cell lines, HT 29 and HUTU 80 (Cezard et al., in preparation).

Acknowledgements. We express our thanks to Miss Chantal Brunet for her careful preparation of the manuscript. This investigation has been supported by the Institut National de la Santé et de la Recherche Médicale (INSERM) (Contrat de Recherche Libre $n^{\circ}$ 78-5-030-4).

\section{References}

1. Andersen O, Gliemann J, Gammeltoft S (1977) Receptor binding and biological effect of insulin in human adipocytes. Diabetologia 13: 589-593

2. Beck-Nielsen H, Pedersen O, Kragballe K, Schwartz Sorensen N (1977) The monocyte as a model for the study of insulin receptors in man. Diabetologia 13: 563-569

3. Beck-Nielsen H, Pedersen O (1979) Insulin binding, insulin degradation and glucose metabolism in human monocytes. Diabetologia 17: 77-84

4. Bihler J (1977) Sugar transport at the basolateral membrane of the mucosal cell. In: Krammer M, Lauterbach F (eds) Intestinal permeation. Excerpta Medica, Amsterdam, p 85-93

5. Brasitus TA, Field M, Kimberg DV (1976) Intestinal mucosal cyclic GMP: regulation and relation to ion transport. Am J Physiol 231: 275-282

6. Carpentier JL, Gorden P, Le Cam A, Freychet P, Orci L (1977) Limited intracellular translocation of ${ }^{125}$ I-insulin in isolated rat hepatocytes. Diabetologia 13: 386

7. Caspary WF (1973) Effect of insulin and experimental diabetes mellitus on the digestive absorptive function of the small intestine. Digestion 9: 248-263

8. Costrini NV, Ganeshappa KP, Wu W, Whalen GE, Soergel $\mathrm{KH}$ (1977) Effect of insulin, glucose, and controlled diabetes 
mellitus on human jejunal function. Am J Physiol 233: E181-E187

9. De Meyts P, Roth J, Neville DM Jr, Gavin JR, III, Lesniak MA (1973) Insulin interactions with its receptors: Experimental evidence for negative cooperativity. Biochem Biophys Res Commun 55: 154-161

10. Forgue ME, Freychet $P$ (1975) Insulin receptors in the heart muscle: Demonstration of specific binding sites and impairment of insulin binding in the plasma membrane of the obese hyperglycemic mouse Diabetes 24: 715-723

11. Forgue-Lafitte ME, Horvat A, Rosselin G (1979) Insulin binding by a cell line (HT 29) derived from human colonic cancer. Mol Cell Endocrinol 14: 123-130

12. Freychet $P$, Roth J, Neville DM Jr (1971) Insulin receptors in the liver: Specific binding of ${ }^{125} \mathrm{I}$-insulin to the plasma membrane and its relation to insulin bioactivity. Proc Natl Acad Sci USA 68: 1833-1837

13. Freychet P, Kahn R, Roth J, Neville DM Jr (1972) Insulin interactions with liver plasma membranes: Independance of binding of the hormone and its degradation. J Biol Chem 247: 3953-3961

14. Freychet P, Rosselin G, Rançon F, Fouchereau M, Broer Y (1974) Interactions of insulin and glucagon with isolated rat liver cells. I-Binding of the hormones to specific receptors. Horm Metab Res (Suppl Ser) 5: 72-78

15. Fromm D, Field M, Silen W (1969) Effects of insulin on sugar, amino acid and ion transport across isolated small intestine. Surgery 66: $145-151$

16. Gavin JR III, Gorden P, Roth J, Archer JA, Buell DN (1973) Characteristics of the human lymphocyte insulin receptor. J Biol Chem 248: 2202-2207

17. Goldfine ID (1977) Does insulin need a second messenger? Diabetes 26: 148-155

18. Guidotti GG, Borghetti AF, Gazzola GC, Tramacere M, Dall' Asta V (1976) Insulin regulation of amino acid transport in mesenchymal cells from avian and mammalian tissues. Biochem J 160: 281-286

19. Hopfer U (1975) Diabetes mellitus: Changes in the transport properties of isolated intestinal microvillous membranes. Proc Natl Acad Sci USA 72: 2027-2031

20. Kahn CR, Freychet P, Roth J (1974) Quantitative aspects of the insulin-receptor interaction in liver plasma membranes. J Biol Chem 249: 2249-2257

21. Kahn CR (1976) Membrane receptors for hormones and neurotransmitters J Cell Biol 70: 261-286

22. Laburthe M, Besson J, Hui Bon Hoa D, Rosselin G (1977) Récepteurs du peptide intestinal vasoactif (VIP) dans les entérocytes: Liaison spécifique et stimulation de l'AMP cyclique. CR Acad Sci [D] (Paris) 284: 2139-2142

23. Laburthe M, Prieto JC, Amiranoff B, Dupont C, Hui Bon Hoa $D$, Rosselin G (1979) Interaction of vasoactive intestinal peptide with isolated intestinal epithelial cells from rat. II-Characterization and structural requirements of the stimulatory effect of vasoactive intestinal peptide on production of adenosine 3': 5'-monophosphate. Eur J Biochem 96: 239-248

24. Le Cam A, Freychet P (1978) Effect of insulin on amino acid transport in isolated rat hepatocytes. Diabetologia 15: $117-123$

25. Le Cam A, Freychet P, Lenoir P (1975) Degradation of insulin by isolated rat liver cells. Diabetes $24: 566-573$

26. Levin RJ (1969) The effects of hormones on the absorptive, metabolic and digestive functions of the small intestine. $J$ Endocrinol 45: 315-348

27. Le Marchand Y, Jeanrenaud B, Freychet P (1978) Insulin binding and effects in the isolated soleus muscle of lean and obese mice. Am J Physiol 234: 348-358

28. Lowry OH, Rosebrough NJ, Farr AL, Randall RJ (1951) Pro- tein measurement with the Folin phenol reagent. J Biol Chem 193: 265-275

29. Mahmood A, Pathak RM, Agarwal N (1978) Effect of chronic alloxan diabetes and insulin administration on intestinal brush border enzymes. Experientia 34: 741-742

30. Maldonato A, Trueheart PA, Renold AE, Sharp GWG (1976) Effects of steptozotocin in vitro on proinsulin biosynthesis, insulin release and ATP content of isolated rat islets of Langerhans. Diabetologia 12: 471-481

31. Ménard D, Malo C (1979) Insulin-evoked precocious appearance of intestinal sucrase activity in suckling mice. Dev Biol 69: $661-665$

32. Mitjavila NT, Mitjavila S, Derache R (1973) Mesures du metabolisme et de la lyse des cellules epithéliales isolées de l'intestin de rat incubées en présence de divers détergents. Toxicology 1: 237-248

33. Olefsky JM, Jen P, Reaven GM (1974) Insulin binding to isolated human adipocytes. Diabetes 23: 565-571

34. Olefsky J, Reaven GM (1974) The human lymphocyte: A model for the study of insulin-receptor interaction. J Clin Endocrinol Metab 38: 554-560

35. Osborne CK, Monaco ME, Lippman ME, Kahn CR (1978) Correlation among insulin binding, degradation, and biological activity in human breast cancer cells in long-term tissue culture. Cancer Res 38: 94-102

36. Pollet RJ, Standaert ML, Haase BA (1977) Insulin binding to the human lymphocyte receptor. Evaluation of the negative cooperativity model. J Biol Chem 252: 5828-5834

37. Prieto JC, Laburthe M, Rosselin G (1979) Interaction of vasoactive intestinal peptide with isolated intestinal epithelial cells from rat. I-Characterization, quantitative aspects and structural requirements of binding sites. Eur J Biochem 96: 229-237

38. Rodbell M (1964) Metabolism of isolated fat cells. I. Effects of hormones on glucose metabolism and lipolysis. J Biol Chem 239: $375-380$

39. Scatchard G (1949) The attraction of proteins for small molecules and ions. Ann NY Acad Sci 51: 660-672

40. Schneider LE, Nowosielski LM, Schedl HP (1977) Insulintreatment of diabetic rats: effects on duodenal calcium absorption. Endocrinology 100: 67-73

41. Taylor SI (1975) Binding of hormones to receptors. An alternative explanation of nonlinear Scatchard plots. Biochemistry 14: $2357-2361$

42. Terris S, Steiner DF (1975) Binding and degradation of ${ }^{125} \mathrm{I}-$ insulin by rat hepatocytes. J Biol Chem 250: 8389-8398

43. Thomopoulos P, Roth J, Lovelace E, Pastan I (1976) Insulin receptors in normal and transformed fibroblasts: Relationship to growth and transformation. Cell 8: 417-423

44. Thomopoulos P, Pessac B (1979) Insulin receptors in cultured mouse retinal cells. Diabetologia 16: 275-279

45. Uchimura I, Wakabayashi T, Mashimo N, Maczawa H (1978) Characteristics of human platelet insulin receptor. Proc Jpn Acad Sci B 54: 490-495

46. Walling MW, Mircheff AK, Van Os CH, Wright EM (1978) Subcellular distribution of nucleotide cyclases in rat intestinal epithelium. Am J Physiol 235: E539-E545

Received: September 3, 1979,

and in revised form: March 18, 1980

M. E. Forgue-Lafitte

INSERM U. 55

184, rue du Faubourg St. Antoine

F-75012 Paris

France 